\title{
O PATRÃO E A PADROEIRA: MOMENTOS DE PERIGO NA PENHA, RIO DE JANEIRO
}

Adriana Facina Carlos Palombini

Articular historicamente o passado não significa conhecê-lo "como ele de fato foi". Significa apropriar-se de uma reminiscência, tal como ela relampeia no momento de um perigo.

(Walter Benjamin, Sobre o conceito da história, 1940).

\section{Abertura}

Para o poeta Olavo Bilac (1919), a música brasileira era a "flor amorosa de três raças tristes": a portuguesa, a africana e a ameríndia. ${ }^{1}$ Fiel ao patrono do serviço militar, a musicologia nacionalista pratica uma xenofobia seletiva: ela oferece à schottisch, à polca, à mazurca e à habanera o passe-livre que recusa ao soul, à disco, ao funk, ao hip-hop, à house e a outras manifestações afro-americanas.

De acordo com a historiografia, o samba nasceu em casa com número, de rua com nome. Desse domicílio, até a planta-baixa é conhecida (Moura 1983:67). ${ }^{2}$ A sala de visitas, da largura do imóvel, se abre sobre a rua, no limite sul da praça. Transposta a sala de visitas, chega-se à de jantar pelo corredor à direita, ao longo de três quartos, à esquerda. Também a sala de jantar tem a largura do imóvel. Ela se comunica com o quintal através de um corredor espremido entre a cozinha e a despensa. Alguns degraus o separam do pátio. É necessário descê-los para chegar-se aos fundos, onde se encontra o quarto de santo. Excetuados a despensa e os quartos de dormir, cada um desses espaços gesta ou acolhe um gênero castiço: choro, partido alto, capoeira, candomblé. Da porta de entrada ao fundo do quintal, passamos da negritude misturada à negritude pura, cujo lugar, em relação à rua, é o mais afastado possível. Ora, o samba não é "uma espécie de bule, onde entram, separados, o café escuro e o leite claro, e de onde jorra, homogêneo e harmônico, o híbrido café com leite" (Bilac 1906b). Ele manifestou seu descontentamento com essa história: 
Já disseram que o samba nasceu num palácio real

E depois se criou e cresceu em salão multicor,

Mas não sabem que o samba nasceu num cruel barracão

E que foi educado sambando no chão com a gente de cor.

(Carmen Miranda, 1938)

Na história do samba, a casa de Tia Ciata tem um Doppelgänger: ${ }^{3}$ a Festa da Penha, na qual, em corpo a corpo com o público, a música era testada. Na expectativa do entusiasmo etílico, afluíam comerciantes portugueses, capoeiras, malandros, sambistas, barraqueiros e tias baianas para o amplo espaço aberto, sem biombos ou compartimentos, disciplinado pela polícia. O mito de fundação do funk carioca ${ }^{4}$ parafraseia a casa de Tia Ciata, com os DJs Big Boy e Ademir Lemos a dividir entre si o papel de tia baiana. A hegemonia do asfalto, reiterada, desloca-se para Botafogo ${ }^{5}$ mas a figura da democracia racial sofre severo abalo: no Baile da Pesada havia soul e funk para o subúrbio dançar e rock progressivo para a Zona Sul viajar. ${ }^{6}$ Organizador do mais politizado dos bailes dos anos 1970, Dom Filó contesta: “O primeiro baile foi na Zona Norte!" (Oliveira Filho \& Cardoso 2010).

A música funk carioca pode ter surgido em clubes na passagem dos anos 1980 para os anos 1990, quando as melôs ${ }^{7}$ cedem lugar aos raps, mas é na década seguinte que ela adquire suas feições atuais: o tamborzão ${ }^{8}$ substitui as bases $^{9}$ de hip-hop, electrofunk, electro e Miami bass; a putaria ${ }^{10}$ e o proibidão ${ }^{11}$ substituem os raps pede-a-paz; ${ }^{12}$ pressionados por políticas ditas de segurança pública, os bailes trocam o asfalto pelo morro. Se partíssemos em busca do Doppelgänger dos Bailes da Pesada nesse período, nos encontraríamos de novo na Penha, Quadra da Chatuba, o Maracanã do Funk - plataforma de lançamento e divulgação de proibidões, de modo análogo à Festa da Penha para o samba antes da era do rádio.

\section{A Festa da Penha}

A Festa da Penha foi, por décadas, a segunda em popularidade no Rio de Janeiro, depois apenas do Carnaval. A Igreja de Nossa Senhora da Penha ergue-se no topo de um penhasco de 111 metros, não longe da atual praia de Ramos, nas proximidades do antigo porto de Maria Angu. O culto local à Santa tem origem em milagre cuja lenda Alexandre José de Mello Moraes Filho recolheu de um octogenário, habitante do local, provavelmente na década de 1850 (Abreu 1999:145). No que então eram matas, um caçador defronta-se com cobra gigantesca e brada: "Valha-me Nossa Senhora da 
Penha!" (Moraes Filho 1895:142). Salta-lhe adiante lagarto indolente que afugenta o vil animal. Pela graça recebida, faz erigir santuário. Obras sucessivas constroem a Igreja acima de 365 degraus esculpidos no granito raro da formação rochosa. Desde o século 18, se não d'antes, ela é centro de festa religiosa a estender-se pelo mês de outubro em romarias de fim de semana.

A Festa foi, de início, religiosa e lusitana. Portugueses, sobretudo os de estratos subalternos, percorriam caminho difícil para pagar promessas e fazer pedidos, ao mesmo tempo que se reuniam para comer e beber iguarias ancestrais. A componente religiosa não se contrapunha à profana, e a Festa tomava ares de festejo popular, criticado na crônica (Assis 2008; Pompéia 1982; Bilac 1906a) e na reportagem. Em 5 de agosto de 1876, Machado de Assis escreve:

Esta festa da Glória é a Penha elegante, do vestido escorrido, da comenda e do claque; a Penha é a Glória da rosca no chapéu, garrafão ao lado, ramo verde na carruagem e turca no cérebro.

Ao cabo de tudo, é a mesma alegria e a mesmíssima diversão, e o que eu lastimo é que o fogo de artifício da Glória e o garrafão da Penha levem mais fiéis que o objeto essencial da festividade. Se é certo que tout chemin mène à Rome, não é certo que tout chemin mène au ciel (Assis 2008:313).

Em relevo, o consumo de bebidas alcoólicas e os chapéus deselegantemente ornados com roscas gigantes, iguaria do festejo. A distância social que separa os romeiros da Glória e os da Penha não impede Machado de equiparar-lhes as motivações sacro-profanas. A contraposição servirá para deslegitimar o caráter religioso da Festa da Penha, se não a Festa mesma. Deduz-se de Moraes Filho que, a despeito de sucessivos esforços de controle eclesial, os romeiros/festeiros não vivenciassem tal oposição. ${ }^{13}$

Moraes Filho publicou Festas populares do Brasil, tradicionalismo, o embrião de Festas e tradições populares do Brasil, em 1888, ainda sem o artigo dedicado à Festa da Penha, que apareceria na edição de 1895. Ele se conclui ali com parágrafos separados do texto por linha pontilhada, indicação de ruptura temporal:14 "Às cusparadas de fogo da locomotiva, a clássica romaria da Penha tem perdido parte de seu caráter devoto e de sua antiga influência" (Moraes Filho 1895:153). A inauguração da primeira linha da Rio de Janeiro Northern Railway Company (futura Leopoldina Railway), em 23 de abril de 1886 (Abreu 1987:53), elevara o número de romeiros. E em 1888 a Abolição levava negros e negras a imprimirem maior nitidez às cores da diáspora africana, práticas religiosas incluídas, na celebração cristã da Penha. Nei Lopes explica: 
E é aí que a festa vai se tornando, cada vez mais, a festa dos bambas (dos "capadócios", para alguns), dos chorões, dos sambistas, dos blocos carnavalescos, dos concursos de música, para ser o grande polo difusor da música popular brasileira, até os anos 50 .

Aí, já não se viam mais as carroças de boi enfeitadas com bambus e colchas de cores berrantes, levando romeiros de chapelões de palha e cordões de roscas no pescoço e a tiracolo. A festa perdia o seu jeito minhoto. O rascante "binho berde" já não corria tão farto. Mas os leilões persistiam e as barracas de comidas, também. Só que, agora, com muito mais samba e choro do que com outra coisa (Lopes 2001:188).

No início do século, a oposição festa/civilização servirá de pano de fundo para a criminalização dos festejos, em relação direta com o enegrecimento sugerido por Lopes. Diferentes cronistas soarão o alarme da ameaça que a Festa constituía para a cidade civilizada, modernamente ordenada, à francesa. Em texto de outubro de 1906, Olavo Bilac evoca a Roma dos primeiros cristãos para dizer que ir à Penha é caminhar para o Martírio pelas batalhas sangrentas da bacanal católica em que todos os desordeiros da cidade marcam ponto (Bilac 1906a). A ideologia dominante do progresso impunha civilização e ordenamento. Em resposta, a regulação policial da diversão popular disciplinará os múltiplos festejos coexistentes. Sabe-se da apreensão do pandeiro de João da Baiana (Vasconcelos 1964:65). Roberto Moura esclarece:

Em 1920, atendendo às pressões que surgiam de cima contra o festejo popular, o chefe de polícia Germiniano de França proibia a presença dos blocos, cordões e rodas de batucada na Penha. Se a proibição não se mantém, a repressão policial é renitente, incidindo principalmente sobre o grupo de sambistas; muitos se afastam em busca da profissionalização que pudesse lhes garantir maiores alternativas nessa sociedade tão afunilada em oportunidades para o negro (Moura 1983:74).

Em testemunho a conflitos e confrontos entre romeiros festeiros e forças da ordem, Augusto de Oliveira Pinto, o Tuiú, trombonista da Banda do Batalhão Naval, compôs o maxixe "Viva a Penha", lançado por Pedro Celestino em 1928.

A polícia não quer barulho, a polícia não quer bebedeira.

E viva a Penha! E viva a Penha! E viva a Santa, nossa Santa padroeira!

Quem fizer barulho vai pro xilindró, com a bebedeira vai ficar falando só.

Pode haver batuque, pode até sambar, a nossa polícia só não pode é ver brigar!

(Pedro Celestino 1928) 
Tornam-se complexas as relações entre o sagrado e o profano, entre a Festa e o conflito, o cristianismo e as religiões afro-brasileiras, os batuques e a polícia. A Festa torna-se complexa. Católica, ela expressa a ideologia dominante, mas a cultura popular e os modos de vida subalternizados também encontram representação, realçada pela crescente interpenetração de culturas negras. A mistura não será pacífica. A Igreja e partes conservadoras do Estado reagirão com violência no "palco de fortes lutas" (Soihet 1998:45) assim constituído. A Festa da Penha adquirirá fama de violência e crime, de malandragem e promiscuidade (Menezes 1996:34). No mês e ano da crônica de Bilac, O Paiz noticiava a ocorrência de um assassinato fato raro (Redação 1906b:2). Do morto, nem o nome, mas o jornal estampa em primeira página caricatura de Julião Machado com a legenda: "Trajo preventivo para os devotos da Penha (Mas alguns romeiros observarão: - E para que serve a dinamite?)" (Redação 1906b:1). O Príncipe dos Poetas a descreve em sua "Crônica": "representa os romeiros, como os guerreiros da idade média, envergando pesadas armaduras de aço, couraças, capacetes e elmos. Não há exagero nisso!" (Bilac 1906a).

Naquele outubro, ao martelar notícias do crime da rua da Carioca (ver Xavier 2004), a Gazeta de Notícias gabava ter-se antecipado à polícia na descoberta do cadáver, e em primeira página dava curso a estas linhas de ficção investigativa:

Como foi encontrado Carluccio - nu, tendo o pescoço fortemente vinculado pelo braço que lhe deu a morte, e amarrado pela cintura a uma corda que o prendia a uma pesada pedra, faz crer mais uma vez que ele tivesse caído numa emboscada que lhe preparam os bandidos.

Um passeio no mar.

Era domingo de festa na Penha. Carluccio tinha lá ido. Alguém - uma mulher talvez, a quem ele dedicava atenções, convidou-o a ir ao arraial em festa, a poética capela da Penha (Redação 1906a:1).

Tida por perigosa, constantemente associada à violência pelos jornais, a Festa é reminiscência ao raiar do milênio: minguam o número de romeiros e a relevância de outubro no calendário festivo. Para estudiosos, frequentadores e a imprensa, isso ocorre nos anos 1990. As múltiplas narrativas atribuem o fato, sobretudo a partir de 1994, ao crescimento da violência armada, cujas causas seriam a dinâmica do comércio de substâncias ilícitas a varejo e iniciativas estatais de combatê-lo por confronto. Em 13 de junho o traficante $^{15}$ Uê mata Orlando Jogador, um dos líderes mais respeitados da facção criminosa Comando Vermelho. ${ }^{16}$ Segue-se uma guerra pela sucessão do poder 
nas favelas cariocas, especialmente no Complexo do Alemão e na região da Penha. A Festa escapa de ser cancelada, mas poucos se atrevem a frequentá-la. A imagem da Santa verte lágrimas de sangue, contam moradores.

Se a violência armada é a causa principal desse declínio, o funk será sua consequência. Ao incluir-se na trilha, ele assinala o fim da velha Penha de Nei Lopes.

Que festa é esta que já não tem mais samba, não tem mais batucada, não tem mais lançamento de músicas para o Carnaval?

$[\ldots]$

E à noite há apenas caixas de som zoando um funk.

Cadê os sambistas, os malandros, os românticos desordeiros?

Cadê a flauta, o cavaquinho, o violão?

[...]

Meu Deus! Eu quero a velha Penha!

(Lopes 2001:189)

Novos tempos, novas sonoridades. E a Festa se reacende nas favelas em volta da Igreja, agora com cânticos e louvores à prosperidade dos patrões do CV. Alegoria da nova Penha, o baile se organiza na Chatuba, menos sacro, mas ligado à Festa velha - uma reminiscência a relampejar num momento de perigo, o eterno retorno da criminalização dos divertimentos de pobres e negros na cidade.

\section{Quadra da Chatuba: O Maracanã do Funk}

Diferentemente da Zona Sul, onde predominam os serviços domésticos e a construção civil, as favelas da Penha são de subúrbio, e lá o operariado fabril prepondera. Essa distinção é parte de um projeto urbano segregativo que assinala as diferenças sociais do trabalho:

Já no final da década de 1950, em que se estabeleceu de forma consistente a relação subúrbio-indústria-proletariado nas áreas dos caminhos do deslocamento das indústrias, há a tendência de representar a favela suburbana da Zona Norte como aquela composta pelo operariado, sendo o modelo sempre referenciado ao Jacarezinho, certamente de grande visibilidade, uma vez que era considerada a maior favela do Rio (Silva 2010:182).

A Chatuba integra o Parque Proletário do Grotão, uma das últimas favelas a surgirem na Penha, a partir de ocupação iniciada em 1979, sobre- 
tudo por nordestinos, que se fixaram numa pedreira desativada, em processo marcado por conflitos de terra (Emop 2010:10-11). Para conquistar a permanência, fundaram a Associação de Moradores do Grotão em 1980 (Cunha 1995). Do mesmo modo que em boa parte das favelas da cidade, os espaços de lazer foram construídos por moradores em sistema de mutirão, e depois melhorados pelo Estado. Parece ser o caso da quadra esportiva da Chatuba, com mais de 30 anos, dizem moradores, remodelada pelo programa urbanístico Favela-Bairro, da prefeitura municipal, na década de 1990.

O Baile começou a tomar corpo em 1996, relatam o produtor cultural Helcimar Lopes, morador do Complexo do Alemão, e Harley Fabiano Fagundes dos Santos, o DJ Byano. ${ }^{17}$ Morador da Chatuba, ele o animou por 16 anos e conduziu-o em seu apogeu, entre 2005 e 2010, quando o comando local do varejo de substâncias ilícitas estava em mãos de Fabiano Atanásio da Silva, o FB, e a Quadra da Chatuba era considerada o Maracanã do Funk por seus frequentadores, entre eles o francês Vincent Rosenblatt, que a fotografou nesse período.

Você chegava na Chatuba, era outro país. A gente não estava mais no Rio de Janeiro, no Brasil. Era um espaço, não sei como explicar. Seria a alegria particular do povo da Penha? Era um caldo de vários fatores que dava certo. Uma incubadora de MCs que estourariam depois: Smith, Max, Orelha, outros. Excelentes DJs: o Napô, da equipe Pitbull, e o Byano, que estourava todos os sucessos, produzidos para o baile e nele testados. Talvez a personalidade dos bandidos do momento, muito festeiros. A mistura da favela com globais: às vezes esta atriz, aquele ator. Jogadores de futebol: o Adriano, que morava perto e não deixava de se divertir. A pessoa sabia que podia ir e jamais alguém mexeria com ela. E o povão funkeiro, para dançar até se acabar. O baile ficava muito lotado, a quadra parecia pequena, e nunca uma briga! Havia uma harmonia coletiva no caos organizado (Rosenblatt \& Palombini 2014).

Compositor de proibidões disputados pelos principais MCs, Thiago Jorge Rosa dos Santos, o Praga, também conhecido por Caneta de Ouro, reside na Penha e confirma: o baile era um grande canal de divulgação. Tornou-se um ponto da juventude carioca porque tinha "uma pegada diferente". ${ }^{18}$ A Loura da Chatuba mantém uma barraca de bebidas ali há 20 anos e corrobora: "A característica do baile era a calma, a tranquilidade de ir e vir, a facilidade de condução". ${ }^{19}$ Essa época de ouro traduziu-se em prosperidade, e ela afirma ter faturado até $\mathrm{R} \$ 3$ mil por noite. Com esse dinheiro, criou os filhos.

A tranquilidade, a fartura, a liberdade, os craques e o formato da quadra, cercada por camarotes, com espaço para se transitar em seu entorno, justi- 
ficam o epônimo. Era outra a situação de acordo com denúncias anônimas propaladas pela Secretaria de Segurança Pública do Estado: "predominavam o consumo de drogas e atos sexuais, inclusive envolvendo exploração de crianças e adolescentes". ${ }^{20} \mathrm{Na}$ perspectiva desses agentes de Estado, os bailes são sempre associados ao crime e constituiriam uma espécie de agit prop do superlativamente denominado tráfico: o Baile da Chatuba seria a principal peça de propaganda do Comando Vermelho.

No camarote, lideranças reunidas do CVRL eram destaque, sobretudo quando, ao som de uma paródia do MC Orelha (2009a) para tema de apresentador televisivo, lançavam dinheiro aos frequentadores. Mais que um elogio à facção, o baile inscrevia-se num tipo de cultura territorial em que identidades se elaboram com referência ao Comando Vermelho, performatizadas por torcedores de facção. ${ }^{21}$ Podemos ler aí uma celebração do Comando sem que isto implique adesão a práticas criminosas, mas a afirmação do local e do compartilhamento da experiência de viver um cotidiano neurótico, marcado pela violência armada e violações diárias de direitos. A reforçar a ideia de uma identidade territorial referenciada em realidade neurótica, ${ }^{22}$ o DJ Byano refere-se ao proibidão como funk da Penha ou funk que fala da Penha. ${ }^{23}$ Tomamos tais expressões como declaração do caráter político do subgênero, relacionado ao compromisso de narrar uma realidade marginalizada e afirmar um poder sobre o território, exercido de dentro por moradores bandidos filiados ao CV.

\section{Proibidão da Penha: “Vida Bandida”}

Os anos da ditadura civil-militar no Brasil, de 1964 a 1985, moldaram uma concepção de música política associada às estéticas de um grupo de compositores e intérpretes provenientes sobretudo das classes médias, cujas dificuldades com o aparato repressivo do Estado tornaram-se conhecidas. Na era dos grandes estúdios, eles firmaram sua autoridade e o prestígio dos selos que os contrataram através de produções dispendiosas cobertas por vendagens de artistas populares (Araújo 2003) - incensadas ano após ano pela crítica especializada nos diários e nos semanários dos grandes conglomerados. Embora diversificadas, tais estéticas apresentavam traços comuns: metáforas mais ou menos rebuscadas, produções fonográficas sofisticadas, arranjadores e instrumentistas consagrados, uma preocupação genérica com o povo e um frisson em torno das relações entre o nacional e o estrangeiro.

O tema das relações entre a população pobre e o aparato repressivo do Estado integra a tradição musical afro-brasileira desde os primórdios da 
indústria fonográfica. Ele se manifesta na canção "Estranguladores do Rio", gravada por Eduardo das Neves em 1907 ou 1908; em "Sete Coroas", "Samba da Favela" 24 de Sinhô publicado em $1922 ;{ }^{25}$ no maxixe de Tuiú anteriormente citado, lançado por Pedro Celestino em 1928; no samba "Metralhadora", de Donga, Luiz Menezes e Haroldo Lobo, gravado por Aurora Miranda em 1933; no samba "Século do progresso", de Noel Rosa, composto em 1934 e gravado por Aracy de Almeida em 1937; no samba "Mulato calado", de Wilson Batista, ${ }^{26}$ gravado por Aracy em 1947; em "Charles, Anjo 45", de Jorge Ben, cantado pelo autor no IV Festival Internacional de Canção em 1969; na "Melô do Mão Branca", letra de Paulo Coelho gravada por Gerson King Combo em 1980; ${ }^{27}$ no partido alto "Se não fosse a ajuda da rapaziada", de Rabanada e Bolão, gravado por Bezerra da Silva em 1992.

O proibidão é definido popularmente por apologia, com elipse do objeto que a música apologizaria. Tal objeto fica subentendido como o crime, o sexo ou ambos. O crime é o comércio de substâncias ilícitas indutoras de estados alterados de consciência, sobretudo a maconha, a cocaína e o crack, excluída a parcela dessa atividade que se realiza fora da favela ou não é praticada por quem tenha origem ali. Ao que resta da subtração denomina-se o tráfico, de modo que o varejo de tais mercadorias passa a representar todos os escalões do comércio ilegal de substâncias e armamentos enquanto atividade criminosa a ser punida. O dispêndio retórico dessa nomeação, na qual uma sinédoque - a parte pelo todo - se oculta por elipse, é inversamente proporcional à legitimidade das medidas com as quais se pune a prática musical. Daí a hipérbole irônica do aumentativo - outra figura dupla de linguagem. Entendemos por proibidão aquela parte da música funk carioca cuja temática diz respeito à vida nos escalões inferiores do comércio de substâncias ilícitas, ou à vida no crime, ${ }^{28}$ narrada com nítida preocupação ética, sem condenação moral explícita, na perspectiva de quem está no problema, de acordo com estéticas específicas de composição, performance e produção fonográfica.

A história recente dos bairros no entorno da serra da Misericórdia, com os Complexos da Penha, no flanco nordeste, e do Alemão, no sudeste, ficou marcada por intervenções do Estado que teriam por objetivo a manutenção da segurança pública em eventos esportivos internacionais. Dessas operações, duas coincidem com o início e o fim de um ciclo musical: a Chacina do Pan (Alvarenga Filho 2010), em 27 de junho de 2007, com as participações da Força Nacional de Segurança Pública e da Polícia Militar do Estado do Rio de Janeiro, e o saldo de 19 execuções; e as invasões e a ocupação dos Complexos da Penha e do Alemão pelas Forças Armadas e as Polícias Federal, Civil e Militar, iniciadas em 25 de novembro de 2010, com saque a moradores e relatos de torturas e execuções (Lima 2015). 
Datado de julho de 2009, "Vida bandida", de Praga, morador da mais antiga das favelas da Penha, a Vila Cruzeiro, é representativo desse apogeu. Wallace Ferreira da Mota, o MC Smith, da região dos morros da Caixa d'Água e do Caracol, também na Penha, estreou-o na madrugada de domingo, 26 de julho de 2009, no Baile da Chatuba, acompanhado pelo DJ Byano à frente da equipe Chatubão Digital. A letra de Praga é precedida por um ad libitum ${ }^{29}$ do $\mathrm{MC}$.

Byano, tu não lançou porque tu esperou eu chegar!

Já tomam'o Chapadão, já tomam'o Jorge Turco,

Breve, breve vamo' p'a Mineira, breve, breve vam' p'o Acari,

Breve, breve, tá, nós vamo' vermelha' a porra toda, meu irmão!

Quem é Comando Vermelho levanta a mão e grita "eu"!

(Mais uma do Byano...)

Partia p'os baile' de briga, pegava carona e roupa emprestada,

Era um dos mais falado', era brabo na porrada.

Mas ninguém vive de fama, queria grana, queria poder:

Se envolveu no Artigo $12^{30}$ pela facção CV.

(FB, se liga só!)

Mas olha ele - quem diria? -, ninguém lhe dava nada,

Tá fortão na hierarquia, abaland'a mulherada.

É o rasante do falcão em cima da R1, ${ }^{31}$

A grossura do cordão tá causando zunzunzum.

Mas é várias mulher, vários fuzil a sua disposição,

O batalhão da área comendo na sua mão.

Ele tem disposição para o mal e para o bem,

Mesmo rosto que faz rir é o que faz chorar também.

Nossa vida é bandida e o nosso jogo é bruto,

Hoje somos festa, amanhã seremos luto.

Caveirão não me assusta, nós não foge do conflito,

Nós também somos blindado' no sangue de Jesus Cristo.

Nossa vida é bandida e o nosso jogo é bruto,

Hoje somos festa, amanhã seremos luto.

Caveirão não me assusta, nós não foge do conflito,

Nós também somos blindado'... 
É que a BMW voa, nós mantem'o pé no chão,

O nosso bonde zoa, nós só chega de patrão.

Só desfolha, ${ }^{32}$ só pacão, ${ }^{33}$ as piranha' passa' mal,

Nós só anda trepadão ${ }^{34}$ de Glock, rajada, G3, Parafal.

Nós estamos no problema, nós não rende pra playboy,

Nós não podemos ir na Zona Sul, a Zona Sul que vem até nós.

Estampado no jornal, toda hora, todo instante,

Patricinha sobe o morro só p'a da' p'a traficante.

Nós não somo' embriagado' nem em fama e nem sucesso

Porque dentro da cadeia todos somos de processo.

Tem que ter sabedoria pra poder viver no crime

Porque bandido burro morre no final do filme.

Nossa vida é bandida e o nosso jogo é bruto,

Hoje somos festa, amanhã seremos luto.

Caveirão não me assusta, nós não foge do conflito,

Nós também somos blindado' no sangue! (MC Smith 2009b)

$\mathrm{O}$ ad libitum compreende as seis linhas iniciais, improvisadas por Smith. ${ }^{35} \mathrm{O}$ MC-soldado conta vantagem, canta vitórias passadas e futuras e, de acordo com a alegoria na qual os termos lançar música e lançar míssil são mutuamente substituíveis, interpela o ouvinte: "Quem é Comando Vermelho levanta a mão e grita 'eu'!". Reverberações localizadas, à maneira do dub, incidem sobre a palavra eu, e a injunção obtém por resposta a pulverização audível desse eu multiplicado. O primeiro caco $^{36}$ de Smith - "Mais uma do Byano!" - prepara rupturas de elocução, personagem e tempo à guisa de aparte ao público.

O MC attacca o recitativo ${ }^{37}$ para contar, no pretérito imperfeito, a vida bandida. O modo é épico porque se trata de um arquétipo de biografia no qual o passado individual se encontra com o passado coletivo nos bailes de briga. Na articulação entre a primeira estrofe e a segunda, Smith endereça um aparte - "FB, se liga só!" - diretamente ao bandido, pois é dele que se fala, em modo heroico, no presente do indicativo, na comemoração de seu aniversário natalício. "Vida bandida" faz as vezes de peça de circunstância.

No refrão (Fig. 1), um arioso ${ }^{38} \mathrm{o} \mathrm{MC}$, o DJ, a comunidade e o bandido comungam em linhas de intensidade insustentável, entremeadas de $v_{\text {vinhetas }}^{39}$ da equipe. Do confronto entre a tragédia do estribilho e o humor das vinhetas surge o grotesco, avesso a catarses sentimentais e propício a suscitar uma modalidade do efeito de estranhamento brechtiano. A reminiscência do ritual cristão religa a performance à gênese da soul music (ver Brackett 2010). 
Figura 1: Estribilho de "Vida bandida" em transcrição de Alexei Michailowsky e Lucas Ferrari ${ }^{40}$
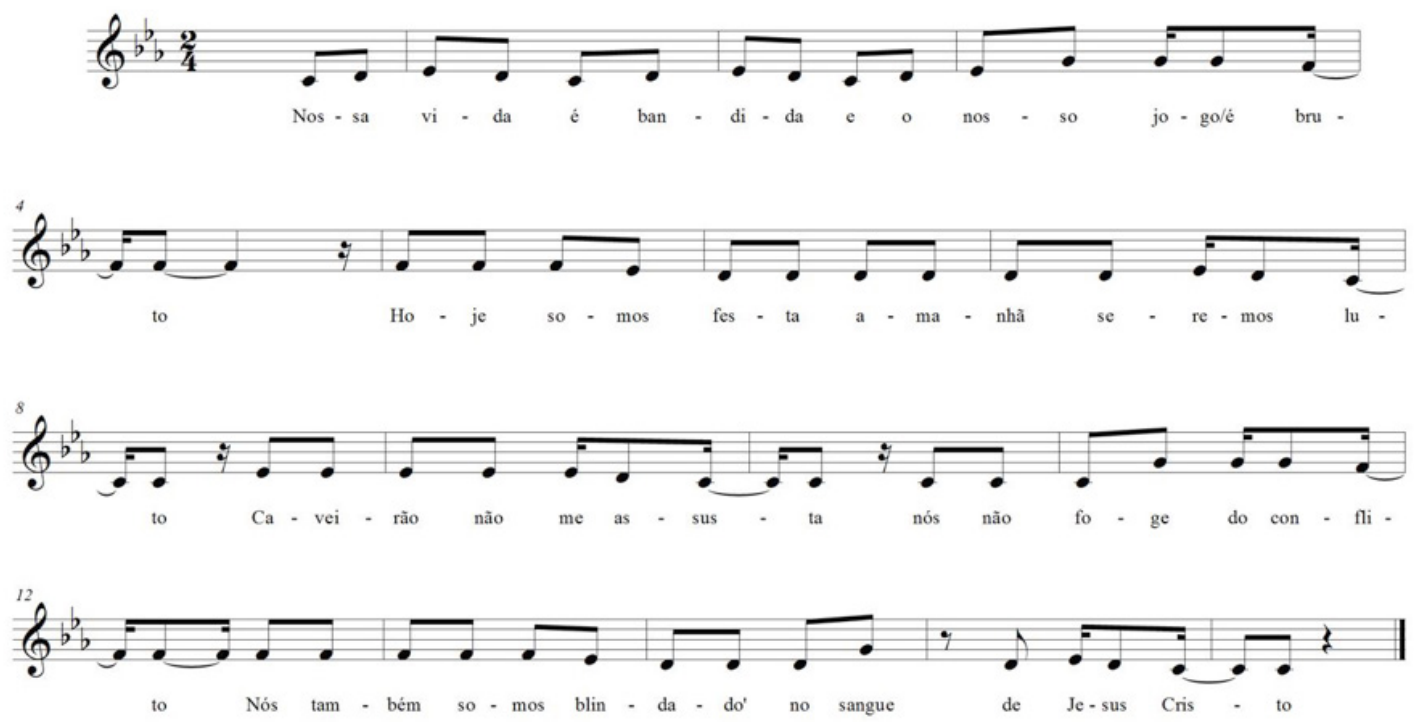

Após a Santa Eucaristia, três estrofes narram a vida bandida na primeira pessoa do plural do presente do indicativo. O estribilho retorna, sem repetição, para ser abruptamente cortado, em sforzato, sobre o "ã" de "sangue", com elipse do "Jesus Cristo" que o concluiria.

A gravação de baile, realizada pelo DJ Zebra, foi para a plataforma 4-Shared no dia da apresentação, e terminaria por suplantar uma produção anterior do DJ Byano (MC Smith 2009c), que aparecera em pelo menos dois canais do Youtube e em duas contas do 4-Shared na quarta-feira, 22 de junho, data de aniversário do FB. Na segunda-feira, 27 de julho, a gravação ao vivo estava em quatro canais do Youtube, que somam hoje, 20 de janeiro de 2015, 4.187.737 visualizações. Postagens e compartilhamentos sucessivos continuaram a propagá-la por Youtube, 4-Shared, Soundcloud, Facebook dia após dia, mês após mês, ano após ano. Na terça-feira, 28 de julho, o Youtube lançava uma coletânea das performances de Smith (2009a). Cinco meses após o Baile, em 26 de dezembro, saía a segunda coletânea, com os MCs Maiquinho, Max, G3, Alexandre, Smith, Frank e Tikão (MC Maiquinho et al. 2009). Quase cinco anos após o Baile, em 11 de maio de 2014, surgia uma grande coletânea, com os MCs Maiquinho, Max, Tikão, G3, Smith, Nike e Orelha (MC Maiquinho et al. 2014). 
"Vida bandida" também chegou ao 4-Shared no domingo de estreia através do CD do Baile (DJ Byano 2009), que reapareceu em outra conta de 4-Shared na segunda-feira. Nesse dia o blog Conexão Proibida anunciou-o, com link para download de uma terceira conta, atualmente inativo. Na quinta-feira ele estava em uma quarta conta, e o blog Studio dos Crias o divulgava, de capa nova, com link, hoje inoperante, para uma quinta conta de 4-Shared. Ainda em julho, ele foi parar no Blog do Thiago Cheradão, com o mesmo link do Conexão Proibida. Em 4 de agosto exibiu-se no blog Baile em Casa, com link de 4-Shared, hoje inativo, para o CD do aniversário errado - o do Bocarra. Finalmente, e a lista não é exaustiva nem leva em conta postagens e links que não deixaram traços visíveis, o blog Funk-RJ divulgou-o, em 3 de setembro, com uma terceira capa e o mesmo link do Studio dos Crias.

Em 2008 o subgênero abandonava o formato da gravação ao vivo ${ }^{41} \mathrm{e}$ apresentava-se nas produções elaboradas do DJ Byano para "Camisa da Osklen" (MC Max e MC Tikão 2008), e do DJ Chorão para "Faz a rodinha em volta da FAP" (MC Max 2008b), ambas de Praga, e para "A Penha é o Poder" (MC Max 2008b), de autoria ignorada, ${ }^{42}$ todas na voz de Max Muller da Paixão Pessanha, da Vila Cruzeiro. E ainda, na de Wallace Felipe Neves Barros, o DJ Corvina, para "Visão de cria", também de Praga, na voz do MC Smith (2008). "Vida bandida" retoma, de forma elaborada, o modo de produção da velha escola. De maneira inversa, outro proibidão de 2009, "Na Faixa de Gaza é assim", de Gustavo Lopes, o MC Orelha (2009b), criado em março, se valeria de recursos mínimos de produção em tempo diferido para construir um simulacro de velha escola (Lopes \& Palombini 2013:18-22). ${ }^{43}$

Se compararmos o álbum com dois dos primeiros CDs de comunidades - o PPG (MCs Cidinho e Doca \& MC Pé de Pano 2002) e o Turano (MC Papel 2002) - teremos ideia do percurso em sete anos dessa fonografia. O PPG divide-se em dois segmentos: 11 faixas com os MCs Cidinho e Doca, da Cidade de Deus; seis faixas com o MC Pé de Pano, do Morro da Formiga. Lincoln, um DJ local, os acompanha. As faixas se sucedem, com cortes, na ordem de apresentação no baile. Cidinho e Doca cantam proibidão. Das seis faixas de Pé de Pano, apenas a segunda e a última se enquadram no subgênero: a primeira é um melody, ${ }^{44}$ a terceira e a quarta são putaria, e a quinta, um discurso abreviado. O Turano apresenta um segmento de seis faixas e outro de oito, ambos na voz do MC Papel, do Morro do Turano. Entre ambos, intercalam-se seis montagens. ${ }^{45}$ Os cortes finais das faixas, algumas separadas por silêncios prolongados, são abruptos e eliminam a maior parte do diálogo. Perde-se assim a continuidade da apresentação ao vivo, evidente no PPG. 
O PPG obtém variedade por alternância entre artistas e subgêneros; e, no segmento inicial, entre canto sobre tamborzão puro (Caceres, Ferrari \& Palombini 2014) e canto a palo seco. ${ }^{46}$ O Turano, por intermissão de montagens; por repetição de raps sobre bases diferentes; e, no segundo segmento, pela participação de convidados.

Longe de ser um registro do Baile, o CD Chatuba: níver do FB (no blog Conexão Proibida), Baile da Chatuba 2009: aniversário do F.B (no Studio dos Crias) ou Chatubão: níver do F.B 2009 (no Funk-RJ) é um retrato da aura do acontecimento, elaborado com os recursos da fonografia e grande elenco, nem todo ele necessariamente presente no evento: em ordem de apresentação no disco, MCs Katia, Maiquinho da Zona Sul, Luan, Ombrinho, Marcelly, Nike, Doriva, Max, Orelha, Star, Tikão, G3, Smith e Frank. O álbum combina os subgêneros proibidão, putaria e montagem, gravados em tempo real (ao vivo) ou diferido (em estúdio). Alguns dos registros ao vivo foram realizados em bailes anteriores ${ }^{47}$ ou mesmo fora da Penha. ${ }^{48}$ As gravações em tempo diferido, que constituem a maior parte das faixas de putaria, são via de regra anteriores ao baile. ${ }^{49}$ Com tal diversidade de vozes, subgêneros, técnicas de produção, locais, datas e procedimentos de gravação, o problema que se apresenta para o DJ-produtor é o da continuidade.

O interlúdio (Fig. 2) remete ao rito em que se atiravam ao público notas de $R \$ 50$ e $R \$ 100$. A produção em tempo diferido liga esta faixa à seguinte, o primeiro proibidão, na voz do mesmo MC. E porque tampouco o segundo proibidão é uma produção ao vivo, passamos imperceptivelmente da putaria, cujo modo normal de produção é o tempo diferido, ao proibidão, cujo modo normal de produção havia sido o tempo real. A partir daí o segmento proibidão caracteriza-se por registros ao vivo entremeados de rimas na hora. ${ }^{50}$

Figura 2: Esquema da alternância entre os subgêneros putaria e proibidão no CD (segunda linha); e da alternância entre as técnicas da produção e da montagem no segmento putaria (terceira e quarta linhas)

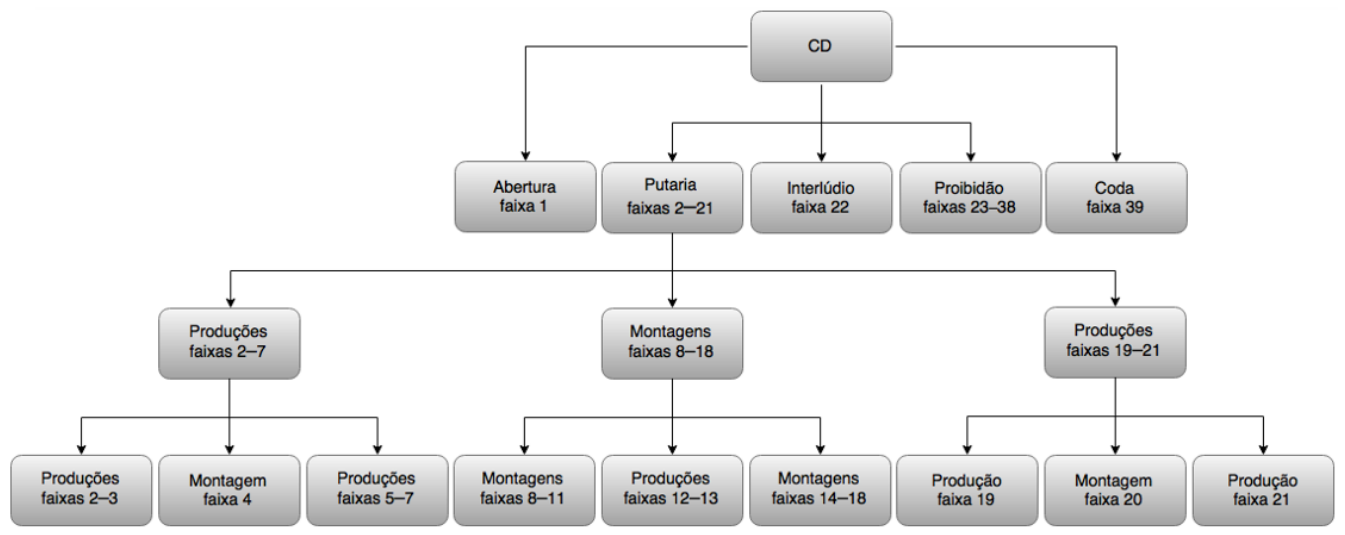


Com exceção da quarta faixa, as montagens aparentam-se às produções e podem fazer uso de vozes de MCs presentes no Baile ou em outras faixas do disco. As produções em tempo diferido não diferem enormemente daquelas ao vivo, e também podem utilizar vozes de MCs presentes no Baile ou em outras faixas no disco. O período de um ano, no qual esses trabalhos foram realizados, garante a homogeneidade de bases, pontos, fórmulas, técnicas, modismos e traços estilísticos, notoriamente voláteis nas músicas eletrônicas dançantes. No subsegmento inicial (Fig. 2, terceira linha), tanto o primeiro quanto o segundo grupo de produções encerram-se na voz do MC Maiquinho; no segundo subsegmento, o primeiro grupo de montagens se abre e se fecha com excertos da mesma música da MC Marcelly. Por fim, a componente criminosa da putaria acentua-se à medida que o proibidão se aproxima.

Embora Praga negue ter-se inspirado no FB, a música teve pré-lançamento na data de seu aniversário, estreou com sua presença durante baile em sua homenagem, cita-o nominalmente, e tornou-se representativa de seu tempo e lugar. Perguntamos ao compositor: qual a importância do FB?

O FB fazia o que o Estado não fazia. Porque se este visse o funk como geração de emprego, o FB não promoveria o baile. A favela está aí, já não há a desculpa do tráfico: a UPP não está aí? Por que não botam baile? Ao contrário, proíbem. A importância do FB consiste em ter feito o que o governador deveria fazer: aproveitar esse espaço e essas pessoas e esse trabalho e empregá-los, ao invés de desempregar, qual fez. O FB dava emprego fora do tráfico, indiretamente. Não éramos traficantes, os MCs não pertenciam ao tráfico. Eles cantavam porque alguém dava oportunidade. A oportunidade que outros deveriam ter dado vinha de um traficante.

Ele vivia do tráfico. Se não mexer com ele, não entrará em seu caminho; se não comprar, você não será afetado; se não usar droga, ela não irá afetá-lo. Compra quem quer. Ele não era um líder comunitário, era um traficante. A única coisa que me beneficiou foi o baile, porque foi através dele que as músicas foram divulgadas. Foi onde surgimos, onde havia equipe de som, barraqueiro, MC. Onde todos faziam parte. Não precisaria ter sido promovido por um traficante, mas foi. ${ }^{51}$ 


\section{Baile pacificado: negociações e sobrevivências}

Com a ocupação militar, em novembro de 2010, dos Complexos da Penha e do Alemão, espetacularmente noticiada na mídia corporativa, ficaram proibidos os bailes funk, inclusive na Chatuba. O estabelecimento de uma Unidade de Polícia Pacificadora ${ }^{52}$ no morro, em 27 de junho de 2012, selou o interdito, malgrado a Empresa de Obras Públicas do Estado ter publicado em 2010 no Caderno Penha: "os jovens têm como principal opção de lazer os bailes funk da Chatuba [...] e da Vila Cruzeiro" (Emop 2010:31). No prisma do DJ Byano, tornou-se questão de honra, para um batalhão, impedir o evento:

Os comandantes diziam que isso era território militar, um troféu do $16^{\circ}$ Batalhão de Polícia Militar. Aqui era reduto do tráfico, não podia botar evento nenhum. [...] Chegaram e proibiram eventos culturais. Dá a entender que seja um tipo de castigo, não? Botam a comunidade de castigo por um bom tempo para depois "avaliar se vai poder". ${ }^{53}$

Na contramão da política de segurança que proíbe bailes em regiões pacificadas, em 2013 a Secretaria de Cultura do Governo do Estado divulgou uma Seleção Pública de Projetos de Bailes e Criação Artística no Funk, a fim de financiar projetos de bailes em favelas com UPPs (Passos \& Facina 2015). A banca contou com policiais militares, parceria inédita das Secretarias de Cultura e de Segurança, a legitimar a autoridade musical da Polícia Militar do Estado do Rio de Janeiro. Contemplado o Baile da Chatuba, Byano e Helcimar, proponentes do projeto, enfrentaram dificuldades. Mesmo com a chancela do Estado, o comandante da UPP negava-se a dar autorização. Somente após troca de comando, em dezembro de 2014, as negociações prosperaram.

A liberação do Baile dependeu da adequação do horário, inicialmente das $21 \mathrm{~h}$ às $2 \mathrm{~h}$, muito cedo para qualquer divertimento noturno no Rio de Janeiro, tanto mais para um baile funk; da contenção do repertório, mormente de músicas que fizessem referência ao crime ou ao sexo explícito, que mencionassem patrões do crime ou tecessem críticas à polícia. O espaço físico já se havia transtornado. Cobriu-se a Quadra, vermelha e branca, com o azul e branco da PMERJ. O Baile seria na sede da UPP, espécie de panóptico onde todos são observáveis por portinholas vazadas à volta da pista, ao alto, nas paredes dos camarotes, ora lacrados.

O edital previu R $\$ 20$ mil para a realização de três bailes-teste, que deveriam assegurar a continuidade do evento em novos moldes - equilíbrio frágil, tecido em negociações múltiplas entre comerciantes de substâncias 
ilícitas, forças policiais, realizadores, barraqueiros, moradores e a Secretaria de Cultura. "Se der qualquer problema, suspendemos o baile", afirmou o comandante, autoridade competente na semântica da problemática. Roberto Carlos abriu a noite de estreia: "eu voltei, agora pra ficar, porque aqui, aqui é meu lugar". O sarcasmo do DJ Byano recebeu a acolhida de sempre, mas enquanto os habitués deploravam as mudanças, os barraqueiros lastimavam o movimento. Ainda assim, lotados os dois primeiros eventos, em 7 e 13 de março de 2015, frequentadores e realizadores exultaram. Mas o dinheiro não circulava - não por ali, em todo caso.

Que restou da identidade territorial musicada em que capoeiragem, malandragem e bandidagem davam as caras? O Baile da Chatuba seria a próxima vítima de bala perdida nesta guerra global às drogas que não cessa de levar a criminalização de pretos e pobres a novos patamares de letalidade? O Maracanã do Funk assistiria hoje à pasteurização de seus bailes, ao apagamento de sua personalidade, qual nosso futebol?

Culturas de sobrevivência negociam para perdurar, instáveis e fluidas, irredutíveis a essências prefixadas (Bhabha 1994). Elas requerem jogo de cintura. A Festa da Penha é reminiscência na Chatuba. O proibidão confronta a pax romana em configurações provisórias. Incipit vita nova. Da Vila Cruzeiro, Praga nos manda um "Trem Bala desgovernado", com o MC Menor do Chapa (2015), do Morro do Turano. A música estreou em vídeo no Youtube em 16 de março de 2015 e terá ao final do dia de hoje, 23 de abril de 2016, mais de 2.394.193 visualizações.

Aqui nós é sinônimo de festa,

Mas também é de cobrança:

Quando nada mais te resta,

É nós que somo' a esperança.

Nós é o dia das crianças,

O Natal e o Ano Novo,

Porque quando chega a Páscoa

Nós que distribui o ovo.

Nós tira do próprio corpo,

Que é pra dar pra quem merece,

Porque eu sei que tudo posso

No Deus que me fortalece.

O crime sempre aparece

Onde o sistema falhou.

Quer pacifica' a favela

Oprimind'o morador. 
Vocês quer falar de paz

Promovendo a violência,

Quem plantar a covardia

Vai colher as consequências.

Assim que é!

Agora é o trem bala desgovernado,

Bate de frente pra ver:

Uma vez que é vida louca,

Vida louca até morrer.

Recuar não é marcar,

Malandragem é viver:

Uma vez que é vida louca,

Vida louca até morrer. (MC Menor do Chapa 2015)

O que importa é estar vivo.

\section{Post-scriptum}

Esta jornada por "múltiplos tempos, espaços e formações culturais" teve por objetivo "abrir decididamente um novo espectro epistemológico e ler as cores que nossos preconceitos haviam previamente apagado" (Serres 1980:23-24). Diante dos limites intelectuais, estéticos, éticos ou políticos da antropologia, da musicologia e da história, colocamo-nos em relação de diálogo autoconsciente, de crítica ou de oposição, de acordo com o modelo agonístico/antagonístico de interdisciplinaridade descrito por Georgina Born (2010:210-213).

Dez anos de trabalho em campo - de 2005 a 2015, quando participamos dos bailes da Penha, observamos seus frequentadores, comerciantes e artistas, conversamos com eles e os entrevistamos formalmente - nos levam a perceber nas festas da Penha a alegoria de longa tradição histórica na qual se articulam a criminalização e a sobrevivência das culturas da diáspora negra na cidade do Rio de Janeiro. Narrar essa história de forma linear ou evolucionista seria sucumbir ao modus operandi dos vencedores. Todo o texto é ficção ou construto (Clifford \& Marcus 1986), e procuramos não fabricar coerências para abafar as dissonâncias da experiência de pesquisa. Daí uma escrita que poderá parecer mais poética que científica. Se a Festa da Penha foi para nós reminiscência que relampejava na Chatuba em perigo 
(ver Benjamin 1985:224-225), também o Baile da Chatuba é reminiscência hoje. A Festa da Penha já o dizia.

"O dom de despertar no passado as centelhas da esperança é privilégio exclusivo do historiador convencido de que também os mortos não estarão em segurança se o inimigo vencer" (Benjamin 1985:224-225).

Recebido em 28 de abril de 2016

Aprovado em 03 de julho de 2017

Adriana Facina é professora do Programa de Pós-Graduação em Antropologia Social, Museu Nacional, Universidade Federal do Rio de Janeiro, Rio de Janeiro, RJ, Brasil. E-mail: <adriana.facina2@gmail.com>

Carlos Palombini é professor da Escola de Música da Universidade Federal de Minas Gerais, Belo Horizonte, MG, Brasil; Programa de Pós-Graduação em Música, Instituto Villa-Lobos, Universidade Federal do Estado do Rio de Janeiro, Rio de Janeiro, RJ, Brasil. E-mail: <cpalombini@gmail.com> 


\section{Notas}

- Este trabalho recebeu o apoio de uma bolsa de produtividade em pesquisa do CNPq. Uma versão preliminar apareceu no livro de Hebe Mattos (2016:113137). Beneficiamo-nos de discussões informais com Alan Brum Pinheiro, Alexandre Negreiros, Barão do Pandeiro, Carlos Sandroni, DJ Zebra, Luiz Antônio Simas, MC Orelha e MC Papo, bem como das colaborações de Bryan Homes e Jorge Vergara.

${ }^{1}$ O leitmotiv das três raças faz parte do programa proposto por Carl Friedrich Philipp von Martius ao Instituto Histórico e Geográfico Brasileiro em 1845.

2 Partimos de Sandroni (2001:100-117); para outras perspectivas críticas, ver Soares (1998), Gomes (2003), Bezerra (2010), Silveira (2012) e Almeida (2013).

${ }^{3}$ Utilizamos o termo Doppelgänger para atribuir ao Baile da Chatuba, na Zona Norte, o papel de mito-sombra do Baile da Pesada, na Zona Sul, por analogia com o papel que a historiografia do samba costuma atribuir à Festa da Penha, na Zona Norte, em relação à casa de Tia Ciata, no Centro.

${ }^{4}$ Ver Ademir Lemos e Oséas Moura dos Santos: apud Frias (1976), que cita Moura dos Santos sob o nome Santos dos Santos (5); apud Vianna (1988:24); apud Thayer (2006:90-91).

${ }^{5}$ Onde acontecia o Baile da Pesada.

${ }^{6}$ Ver Moura dos Santos: apud Essinger (2005:19); apud Thayer (2006:90); apud Oliveira Filho e Cardoso (2010). Thayer oferece uma variante ao dizer que a dicotomia caracterizasse o Baile da Cueca, evento semanal organizado por Big Boy na Zona Sul anteriormente ao Baile da Pesada. Infere-se que, neste, a participação de Ademir Lemos houvesse solucionado o problema. Santos era seguidor confesso de Lemos (Assef 2003:47) e dá a entender que a dicotomia se resolva nos bailes de sua própria equipe; ver Santos (apud Frias 1976:5; apud Assef 2003:47; apud Essinger 2005:19).

${ }^{7}$ Versões em português, baseadas em homofonia, do refrão de música afro-americana executada nos bailes. Assim, "You Talk Too Much", do trio de hip-hop de Nova York, Run-D.M.C (1985), dá origem a "Taca tomate"; "I'll Be All You Ever Need", da cantora de freestyle de Miami, Trinere (1986), transforma-se em "Ravioli eu comi"; "Whoomp! (There It Is)", do duo de hip-hop de Atlanta, Tag Team (1993), torna-se "Uh, tererê!".

${ }^{8}$ Base (ver infra) criada em 1998 pelo DJ Luciano, de Campo Grande (Caceres, Ferrari \& Palombini 2014:86-196).

${ }^{9}$ Nos anos 1990, no funk carioca, versão instrumental, no lado B de singles importados, utilizada como suporte rítmico da voz.

${ }^{10}$ Subgênero de funk carioca com letras sexualmente explícitas, uma das principais vertentes, sobretudo a partir da virada do milênio. 
${ }^{11}$ Subgênero de funk carioca cujas letras se referem à vida no crime (ver infra), outra das principais vertentes, cujo apogeu se situa na primeira década do milênio.

${ }^{12}$ Estilo característico dos anos 1990, com letras que pregam a paz nos bailes, então marcados por brigas de galeras.

${ }^{13}$ Uma vez que não nos é possível reproduzir em sua integralidade o texto de Moraes Filho, recomendamos vivamente ao leitor remeter-se à versão disponível na rede (Moraes Filho 2002).

${ }^{14}$ Esses parágrafos poderiam constituir adições a uma suposta reedição, mas não nos foi possível localizar publicação anterior à de 1895 que incluísse o artigo sobre a Festa da Penha (ver Abreu 1999:166, nota 47).

${ }^{15}$ Usamos o termo traficante em itálico por se tratar de categoria nativa que superestima o papel dos comerciantes varejistas das favelas na rede internacional do tráfico, e assim contribui para a criminalização do local e seus moradores (ver "tráfico", infra).

${ }^{16}$ Sobre o Comando Vermelho Rogério Lemgruber (CVRL), Comando Vermelho (CV) ou, simplesmente, "O Comando", ver Lima (1991), Cypriano (2001) e Barcellos (2003).

${ }^{17}$ DJ Byano, entrevista, 7 mar. 2015.

${ }^{18}$ Praga, entrevista, 25 jun. 2015.

${ }^{19}$ Loura da Chatuba, entrevista, 15 maio 2015.

20 "FB", Procurados.org. Disponível em http://goo.gl/sP5Ojq. Acesso em 12/10/ 2015.

${ }^{21}$ DJ Byano, entrevista, 7 mar. 2015.

${ }^{22}$ Sobre os termos neurose e neurótico, ver Mattos $(2006,2012)$.

${ }^{23}$ DJ Byano, entrevista, 7 mar. 2015.

24 "Homenagem a seu modo a famoso bandido do Morro da Favela" (Alencar 1981:149), atual Morro da Providência, na Zona Portuária do Rio de Janeiro.

${ }^{25}$ A primeira gravação vocal, com o grupo Lira Carioca, data do ano 2000.

${ }^{26}$ O site da União Brasileira de Compositores mostra que "Mulato calado", registrada no Escritório Central de Arrecadação e Distribuição sob o número 1.526, seja de Benjamim Baptista Coelho e Marina Baptista, tio e esposa do compositor. O catálogo on-line do Instituto Moreira Salles indica que a partitura foi publicada em 1947 pela Editora Todamérica sob os nomes de José Batista e Benjamim Batista. Jairo Severiano, Daniela Thompson, Carlos Sandroni e Paulo César de Andrade atribuem a composição a Wilson Batista. Andrade explicou-se a Sandroni em mensagem de 2 de fevereiro de 2010, que citamos com a permissão do destinatário: "Wilson Batista várias vezes usou em sua carreira outros nomes, parece que para driblar obrigações contratuais com as editoras e gravadoras de músicas. Benjamin Batista, Marina Batista (sua mulher, por um tempo) e J. Batista foram os mais usados". 
${ }^{27}$ Segundo Gerson King Combo (em mensagem de 22 jun. 2014), a letra seria de Pedro da Luz e Robert (sic) Livi. Datada de $1^{\circ}$ de janeiro de 1980, letra diferente aparece sob o mesmo nome no website da Fundação Paulo Coelho (ver http://goo. gl/6vqBCh. Acesso em 11/06/2015). De acordo com Hérica Marmo (2007:182-184), Roberto Livi, Pedrinho da Luz e Paulo Coelho participaram do projeto, e o grupo Famks, mais tarde Roupa Nova, gravou o instrumental. O selo do compacto atribui autoria a Rocha, Carmem e Barra. Perguntamos ao cantor quem seriam: "Não tenho a menor ideia; pode ser pseudônimo adotado" (22 jun. 2014). O lançamento é anterior a 25 de maio, conforme carimbos em cópia que pertenceu à Discoteca AM da Rádio Record (ver http://goo.gl/u7E6PE. Acesso em 11/06/2015). Sobre o Mão Branca e seu contexto, ver Alves (2003:149-172).

${ }^{28}$ Também, a vida no contexto, no movimento; a vida de quem tem envolvimento, de quem é ou está envolvido. Ou ainda, genericamente (sem implicação necessária de comprometimento direto com o comércio de substâncias ilícitas): a vida no problema; a atividade, cf. estar na atividade, i.e., estar furtando, assaltando, traficando etc.

${ }^{29}$ Improvisação ex nihilo (Fuller 2015).

${ }^{30}$ Art. 12 da Lei 6.368/1976, de 21 de outubro (revogada pela Lei 11.343/2006, de 23 de agosto): "Importar ou exportar, remeter, preparar, produzir, fabricar, adquirir, vender, expor à venda ou oferecer, fornecer ainda que gratuitamente, ter em depósito, transportar, trazer consigo, guardar, prescrever, ministrar ou entregar, de qualquer forma, a consumo substância entorpecente ou que determine dependência física ou psíquica, sem autorização ou em desacordo com determinação legal ou regulamentar."

${ }^{31}$ Motocicleta Yamaha YZF-R1.

${ }^{32}$ Substantivo feminino, do verbo desfolhar: ato de subtrair, para gastá-las, notas de um maço de dinheiro.

${ }^{33}$ Substantivo masculino: o maço de dinheiro, objeto direto da desfolha.

${ }^{34}$ Aumentativo de trepado, particípio passado do verbo trepar, em função adjetiva: fortemente armado.

${ }^{35}$ MC Smith, entrevista, 9 fev. 2015.

${ }^{36}$ Praga utiliza o termo com referência ao jargão teatral: pequena fala que o ator enxerta no texto em função da personagem e da encenação.

37 "Tipo de escrita vocal [...] cujo objetivo é imitar a fala dramática na canção" (Budden, Monson \& Westrup 2015).

38 "Estilo similar ao da canção, em contraposição ao da declamação; uma passagem curta, em andamento regular, no meio ou no fim de um recitativo" (Budden, Carter, McClymonds, Murata \& Westrup 2015)

${ }^{39}$ Samples com a assinatura do DJ e da equipe disparados durante a execução ou inseridos em pós-produção. 
${ }^{40}$ Incluímos uma transcrição do estribilho de "Vida bandida" à guisa de ilustração musical porque o subgênero encontra enorme dificuldade em ser analisado em sua organização sonora.

41 “Já em 2002 uma forma de música funk conhecida como proibidão estava firmemente estabelecida, um movimento de canções underground sobre o poder e as atividades do crime organizado, que são cantadas ao vivo em bailes funk nas favelas ou estão disponíveis em gravações-pirata desses shows" (Sneed 2003:51-52).

${ }^{42}$ Esse rap costuma ser apresentado sob o nome "Fábrica de bico" quando adaptado a contextos locais. Foi o que fez o MC Zoi de Gato. O fato deu origem à controvérsia segundo a qual o MC Max o teria roubado. Mas a produção do DJ Chorão encontra-se no Youtube desde 19 de setembro de 2008, enquanto a postagem mais antiga da versão de Zoi de Gato data de 2 de maio de 2009. A expressão "fábrica de bico" parece ter sido tomada do rap "Fábrica de bico", do MC GaRgA (2007), de Venda Velha, São João do Meriti, no 4-Shared desde 25 de outubro de 2007.

${ }^{43}$ Estes e outros fatos sugerem a hipótese de que, em suas grandes crises cíclicas, o funk carioca se reinvente de modo retrospectivo, por ruminação de raízes.

${ }^{44}$ Subgênero romântico de funk carioca.

${ }^{45}$ Subgênero que se caracteriza pela autonomia do DJ-produtor ao selecionar material heterogêneo, especialmente vozes, e organizá-lo de forma fragmentária e repetitiva.

${ }^{46}$ Diz-se do canto sem acompanhamento.

${ }^{47}$ É o caso das faixas 19, 25 e 33, com Nike, provavelmente gravadas na Chatuba em julho de 2008; no 4-Shared desde 21 mar. 2009.

${ }^{48}$ É o caso da faixa 13, gravada no Morro da Barão, na Praça Seca, Zona Oeste, parte do CD Barão-Méier, no 4-Shared desde 29 jul. 2009 (DJ Amarelo e DJ Zebra 2009). É o caso das faixas 30, no 4-Shared desde 6 jul. 2009, e 21, 29 e 34, no 4-Shared desde 12 abr. 2009, todas gravadas no Chapadão, Zona Norte.

${ }^{49}$ É o caso das faixas 2, no Youtube desde 26 abr. 2009; 3, no 4-Shared desde 18 fev. 2009; 5, no Youtube desde 20 maio 2009; 7, no 4-Shared desde 18 fev. 2009; 8, no Youtube desde 12 jul. 2009; 9, no Youtube e no 4-Shared desde 24 mar. 2009; 11, no 4-Shared desde 30 jun. 2009; 12, no Youtube desde 3 jul. 2009; 15, no Youtube desde 15 abr. 2009; 16, no Youtube desde 17 jun. 2009; 17, no Youtube desde 15 out. 2008 sob o nome "Conflitos penetrantes, conflitos sexuais (parte 2)", provavelmente a gravação mais antiga do CD; 18, no Youtube desde 29 mar. 2009; e 19 (ver nota 47 supra).

${ }^{50}$ Improviso vocal rimado, em prelúdio, interlúdio ou poslúdio ao rap.

${ }^{51}$ Praga, entrevista, 14 jun. 2013.

${ }^{52}$ As UPPs foram criadas para ocupar militarmente territórios valorizados, parte dos esforços preparatórios para a Copa do Mundo de 2014 e as Olimpíadas de 2016, e de amplo processo de elitização de algumas áreas, conforme a ideia de cidade-mercadoria. Nunca houve exposição de princípios, objetivos e métodos, notoriamente voláteis. Em julho de 2013, o desaparecimento do ajudante de pedreiro Amarildo de Souza, torturado e morto por policiais da UPP da Rocinha, escancarou as violações de direitos por policiais e agravou a crise do projeto.

${ }^{53}$ DJ Byano, entrevista, 7 mar. 2015. 


\section{Referências bibliográficas}

ABREU, Martha. 1999. O império do Divino: festas religiosas e cultura popular no Rio de Janeiro, 1830-1900. Rio de Janeiro e São Paulo: Nova Fronteira.

ABREU, Mauricio de Almeida. 1987. Evolução urbana do Rio de Janeiro. Rio de Janeiro: Iplanrio/Zahar.

ALENCAR, Edigar de. 1981. Nosso Sinhô do samba. Rio de Janeiro: Funarte.

ALMEIDA, Angélica Ferrarez de. 2013. A tradição das tias pretas na Zona Portuária: por uma questão de memória, espaço e patrimônio. Dissertação de Mestrado, PUC-Rio.

ALVARENGA FILHO, José Rodrigues de. 2010. A "Chacina do Pan" e a produção de vidas descartáveis na Cidade do Rio de Janeiro. Dissertação de Mestrado, UFF.

ALVES, José Cláudio Souza. 2003. Dos barões ao extermínio: uma história da violência na Baixada Fluminense. Duque de Caxias: APPH-Clio.

ARAÚJO, Paulo Cesar de. 2003. Eu não sou cachorro não: música popular cafona e ditadura militar. Rio de Janeiro: Record.

ASSEF, Cláudia. 2003. Todo DJ já sambou: a história do disc-jóquei no Brasil. São Paulo: Conrad.

ASSIS, Machado de. 2008. História de quinze dias. In: A. Leite, A. L. Cicilio \& H. Jahn (orgs.), Obra completa em quatro volumes. Vol. 4. Rio de Janeiro: Aguilar. pp. 313-316 [Originalmente publicado em Ilustração brasileira, Rio de Janeiro, 15 ago. 1876].

BARCELLOS, Caco. 2003. Abusado: o dono do Morro Dona Marta. Rio de Janeiro e São Paulo: Record.

BENJAMIN, Walter. 1985 [1940]. "Sobre o conceito da história". In: Obras escolhidas I. Trad. Sergio Paulo Rouanet. São Paulo: Brasiliense. pp. 222-232.
BEZERRA, Nielson Rosa. 2010. Mosaicos da escravidão: identidades africanas e conexões atlânticas do Recôncavo da Guanabara (1780-1840). Tese de Doutorado, UFF.

BHABHA, Homi K. 1994. The location of culture. Londres e Nova York: Routledge.

BILAC, Olavo. 1919. "Música brasileira". In: Tarde. Rio de Janeiro, São Paulo e Belo Horizonte: Livraria Francisco Alves. pp. 18-19.

—. 1906a. "Crônica". In: Kosmos, $\operatorname{III}(10): \mathrm{s} / \mathrm{p}$.

—. 1906b. "A dança no Rio de Janeiro". In: Kosmos, III(5):s/p.

BORN, Georgina. 2010. "For a relational musicology: music and interdisciplinarity, beyond the practice turn". Journal of the Royal Musical Association, CXXXV(2):205-243.

BRACKETT, David. 2010. "Música soul". Trad. Carlos Palombini. Opus: revista da Anppom, XV(1):62-68.

BUDDEN, Julian; CARTER, Tim; MCCLYMONDS, Marita P.; MURATA, Margaret \& WESTRUP, Jack. 2015. "Arioso". In: Grove music online. Nova York: Oxford University Press. Disponível em: http://goo.gl/IMrAqL. Acesso em 30/06/2015.

BUDDEN, Julian; MONSON, Dale E. \& WESTRUP, Jack. 2015. "Recitative". In: Grove music online. Nova York: Oxford University Press. Disponível em: http://goo.gl/Dz4rJE. Acesso em 30/06/2015.

CACERES, Guillermo; FERRARI, Lucas \& PALOMBINI, Carlos. 2014. "A era Lula/Tamborzão: política e sonoridade". Revista do IEB, LVIII:157-207.

CLIFFORD, James \& MARCUS, Georg (orgs.). 1986. Writing culture: The poetics and politics of ethnography. Berkeley e Los Angeles: University of California Press. 
CONGRESSO NACIONAL. 2006. Lei 11.343. Diário Oficial da União, Seção 1, 24 ago. Disponível em: http://goo.gl/wLuEbp. Acesso em 22/04/2016.

—. 1976. Lei 6.368. Diário Oficial da União, Seção 1, 22 out. Disponível em: http://goo.gl/uVBJtE. Acesso em 7/02/2016.

CUNHA, Marize Bastos da. 1995. Grotão, Parque Proletário, Vila Cruzeiro e outras moradas: história e saber nas favelas da Penha. Dissertação de Mestrado, UFF.

CYPRIANO, André. 2001. O caldeirão do Diabo. São Paulo: Cosac \& Naify.

EMOP. 2010. Caderno Penha. Rio de Janeiro: Empresa de Obras Públicas do Estado do Rio de Janeiro. Disponível em: http://goo.gl/nHTjeY. Acesso em 12/10/2015.

ESSINGER, Silvio. 2005. Batidão: uma história do funk. Rio de Janeiro: Record.

FRIAS, Lena. 1976. "Black Rio: o orgulho (importado) de ser negro no Brasil". Jornal do Brasil, Caderno B, pp. 1, 4-6, 17 jul.

FULLER, David. 2015. "Ad libitum". In: Grove music online. Nova York: Oxford University Press. Disponível em: http://goo.gl/rXifQ9. Acesso em 30/06/2015.

GOMES, Tiago de Melo. 2003. "Para além da casa de tia Ciata: outras experiências no universo cultural carioca, 1830-1930". Afro-Ásia, XXIX/ XXX:175-198.

LIMA, Tatiana da Silva. 2015. Onde estão os mortos? Silenciamentos, discursos e os sentidos midiáticos da pacificação do Complexo do Alemão. Dissertação de Mestrado, UFF.

LIMA, William da Silva. 1991. Quatrocentos contra um: uma história do Comando Vermelho. Petrópolis: Vozes.
LOPES, Gustavo \& PALOMBINI, Carlos. 2013. "Entrevista com Gustavo Lopes, o MC Orelha". In: C. B. Batista (org.), Tamborzão: olhares sobre a criminalização do funk. Rio de Janeiro: Revan. pp. 13-28.

LOPES, Nei. 2001. Guimbaustrilho e outros mistérios suburbanos. Rio de Janeiro: Dantes.

MARMO, Hérica. 2007. A canção do Mago: a trajetória musical de Paulo Coelho. São Paulo: Futuro.

MARTIUS, Carlos Frederico P. de. 1845 "Como se deve escrever a história do Brasil". Revista Trimensal de História e Geografia, VI(24):381-403.

MATTOS, Carla dos Santos. 2012. "Da valentia à neurose: criminalização das galeras funk, 'paz' e (auto)regulação das condutas nas favelas". Dilemas: Revista de Estudos de Conflito e Controle Social, V(4):653-680. . 2006. No ritmo neurótico: cultura funk e performances "proibidas" em contexto de violência no Rio de Janeiro. Dissertação de Mestrado, UERJ.

MATTOS, Hebe (org.). 2016. História oral e comunidade: reparações e culturas negras. São Paulo: Letra e Voz.

MENEZES, Renata de Castro. 1996. Devoção, diversão e poder: um estudo antropológico sobre a Festa da Penha. Dissertação de Mestrado, UFRJ.

MORAES Filho, Alexandre José de Mello. 2002. "A Festa da Penha". In: Festas e tradiçóes populares do Brasil. Brasília: Senado Federal. pp. 131-140. Disponível em: http://goo. gl/dOfX3M. Acesso em 8/04/2017.

- 1895. Festas e tradições populares do Brasil. Rio de Janeiro: Fauchon.

-. 1888. Festas populares do Brasil: tradicionalismo. Rio de Janeiro: Garnier. MOURA, Roberto. 1983. Tia Ciata e a pequena África no Rio de Janeiro. Rio de Janeiro: Funarte. 
OLIVEIRA FILHO, Asfilófio de \& CARDOSO, Edson. 2010. "Black Rio, Filó: uma nova postura do negro, num contexto de repressão e autoritarismo". Círculo Palmarino. Disponível em: http://goo.gl/bgBpvY. Acesso em 2/06/2015.

PASSOS, Pâmella \& FACINA, Adriana. 2015. “'Baile modelo!': reflexões sobre práticas funkeiras em contexto de pacificação". VI Seminário Internacional de Políticas Culturais. Rio de Janeiro: Casa de Rui Barbosa, 26-29 maio. Disponível em: http://goo. gl/ZQXmAH. Acesso em 13/10/2015. POMPÉIA, Raul. 1982. "A vida na corte". In: A. Coutinho (org.), Obras VI: Crônicas I. Rio de Janeiro: Civilização Brasileira/Olac. pp. 96100. [Originalmente publicado em Diário de Minas, Juiz de Fora, 4 nov. 1888].

REDAÇÃO. 1906a. "O aparecimento do cadáver". Gazeta de Notícias, XXXII(291):1-2.

REDAÇÃO. 1906b. [Sem título]. O Paiz, XXIII(8049):1-2, 17 out.

ROSENBLATT, Vincent \& PALOMBINI, Carlos. 2014. "Vincent na Chatuba". Proibidao.org, 27 dez. Disponível em: http://goo.gl/iQiAwN. Acesso em 12/10/2015.

SANDRONI, Carlos. 2001. Feitiço decente: transformações do samba no Rio de Janeiro (1917-1933). Rio de Janeiro: Jorge Zahar/Editora UFRJ.

SERRES, Michel. 1980. Hermès V: le passage du Nord-ouest. Paris: Minuit.
SILVA, Maria Lais Pereira da. 2010. "A favela e o subúrbio: associações e dissociações na expansão suburbana da favela". In: M. P. de Oliveira \& N. da N. Fernandes (orgs.), 150 anos de subúrbio carioca. Rio de Janeiro: Lamparina. pp. 161-186.

SILVEIRA, Leandro Manhães. 2012. Nas trilhas de sambistas e "povo do santo": memórias, cultura e territórios negros no Rio de Janeiro (19051950). Dissertação de Mestrado, UFF. SNEED, Paul. 2003. Machine gun voices: bandits, favelas and utopia in Brazilian funk. Tese de Doutorado, University of Wisconsin-Madison.

SOARES, Carlos Eugênio Líbano. 1998. Zungu: rumor de muitas vozes. Rio de Janeiro: Arquivo Público do Estado do Rio de Janeiro.

SOIHET, Rachel. 1998. A subversão pelo riso: estudos sobre o carnaval carioca da Belle Époque ao tempo de Vargas. Rio de Janeiro: FGV.

THAYER, Allen. 2006. "Black Rio: Brazilian soul and DJ culture's lost chapter". Wax Poetics, XVI:88-106.

VASCONCELOS, Ary. 1964. Panorama da música popular brasileira. Vol. 1. São Paulo: Martins Fontes.

VIANNA, Hermano. 1988. O mundo funk carioca. Rio de Janeiro: Jorge Zahar.

XAVIER, Valêncio. 2004 . "Os estranguladores da Fé em Deus: os crimes de Rocca e Carletto". In: Crimes à moda antiga: contos verdade. São Paulo: Publifolha. pp. 6-25.

\section{Referências fonográficas}

ARACY DE ALMEIDA. 1947. "Mulato calado". De Wilson Batista. Odeon 12.767-B. Disponível em: http://goo. gl/zx7RO7. Acesso em 12/10/2015.
—. 1938. "Século do progresso". De Noel Rosa, 1934. Victor 34.296-B. Disponível em: http://goo.gl/zx7RO7. Acesso em 12/10/2015. 
AURORA MIRANDA. 1934. "Metralhadora". De Donga, Luiz Menezes e Haroldo Lobo. Odeon 11.091-B. Disponível em: http://goo.gl/9wv7pD. Acesso em 12/10/2015.

BEZERRA DA SILVA. 1992. "Se não fosse a ajuda da rapaziada". De Rabanada e Bolão. Presidente caô caô. RCA 130.0153. Disponível em: http://goo. gl/zx7RO7. Acesso em 12/10/2015.

CARMEN MIRANDA. 1938. "Quem condena a batucada", de Nelson Petersen. Odeon 11.640-B.

DJ AMARELO \& DJ ZEBRA. 2009. Barão-Méier. Com os MCs Orelha, Ombrinho, Foguinho, Mamão, Luan e equipe Chatubão Digital. Disponível em: http://goo.gl/Vuqdze. Acesso em 13/10/2015.

DJ BYANO. 2009. Chatubão Digital: níver do FB. Prod. DJ Byano, gravação DJ Zebra, equipe Chatubão Digital. Disponível em: http://goo.gl/HY0HYA. Acesso em 13/10/2015.

EDUARDO DAS NEVES. 1907. "Estranguladores do Rio". Odeon 108.084. Disponível em: http://goo.gl/dO8Lbb. Acesso em 12/10/2015.

GERSON KING COMBO. 1980. "Melô do Mão Branca". De Roberto Livi, Pedro da Luz e Paulo Coelho. Sinter 2.171.603. Disponível em: http://goo. gl/g8tMgt. Acesso em 12/10/2015.

JORGE BEN. 1969. "Charles, Anjo 45". Jorge Ben. Philips R 765.100 L. Disponível em: http://goo.gl/zx7RO7. Acesso em 12/10/2015.

LIRA CARIOCA (com Clara Sandroni e Marcos Sacramento). 2000. "Sete Coroas". De Sinhô, 1922. É sim, Sinhô, vol. 2. Lira Carioca FS445. Disponível em: http://goo.gl/Stlfio. Acesso em 30/10/2015.

MC GARGA. 2007. "Fábrica de bico". Disponível em: https://goo.gl/ DUMvrt. Acesso em 25/04/2016.
MC MAIQUINHO et al. 2014. "No Baile da Chatuba". Disponível em: http://goo.gl/xwpqJT. Acesso em 13/10/2015.

—. 2009. "No Baile da Chatuba". Disponível em: http://goo.gl/eYvbis. Acesso em 13/10/2015.

MC MAX. 2008a. "A Penha é o Poder". De autor ignorado, prod. DJ Chorão. Disponível em: http://goo.gl/ MXwni3. Acesso em 13/10/2015.

-. 2008b. "Faz a rodinha em volta da FAP". De Praga, prod. DJ Chorão. Disponível em: http://goo.gl/cdtiVE. Acesso em 13/10/2015.

MC MAX \& MC TIKÃO. 2008. "Camisa da Osklen". De Praga, prod. DJ Byano. Disponível em: http://goo.gl/ dyfNKf. Acesso em 13/10/2015.

MC MENOR DO CHAPA. 2015. "Trem Bala desgovernado". De Praga, vídeo de Kondzilla. Disponível em: http://goo.gl/Z2tZZE. Acesso em 23/04/2016.

MC ORELHA. 2009a. "Chatuba, terra de Sílvio Santos". Do MC Orelha, prod. DJ Byano. Disponível em: http://goo. gl/kg22Ud. Acesso em 12/10/2015.

-. 2009b. "Na Faixa de Gaza é assim". Do MC Orelha, prod. MC Orelha. Disponível em: http://goo.gl/4Swtk6. Acesso em 23/04/2016.

MC PAPEL. 2002. Turano. Ao vivo no Turano. Disponível em: http://goo. gl/6jfWDw. Acesso em 13/10/2015.

MC SMITH. 2009a. "MC Smith no Baile da Chatuba". Músicas de Cláudio da Maragogi e Praga, prod. DJ Byano. Disponível em: http://goo.gl/Edjgdi. Acesso em 13/10/2015.

—. 2009b. "Vida bandida". De Praga, prod. DJ Byano, ao vivo na Chatuba. Disponível em: http://goo.gl/ yb1NBm. Acesso em 13/10/2015.

—. 2009c. "Vida bandida". De Praga, prod. DJ Byano. Disponível em: http://goo.gl/E6yjP5. Acesso em 13/10/2015. 
—. 2008. "Visão de cria". De Praga, prod. DJ Corvina. Disponível em: http://goo.gl/GVRosx. Acesso em 13/10/2015.

MCs CIDINHO e DOCA \& MC PÉ DE PANO. 2002. PPG. Com o DJ Lincoln, ao vivo no Pavão-Pavãozinho-Cantagalo. Disponível em: http:// goo.gl/6ftVuC. Acesso em 13/10/2015. PEDRO CELESTINO. 1928. "Viva a Penha". De Tuiú. Odeon 10.095. Disponível em: http://goo.gl/FA5DLZ. Acesso em 9/10/2015.

RUN-D.M.C. 1985. "You Talk Too Much", de Larry Smith, Joseph Simmons (Run), Russell Simmons, Darryl McDaniels (D.M.C), Jason Mizell (Jam Master Jay) e Daniel Hayden, prod. Russell Simmons e Larry Smith. Profile, PRO-7069.
TAG TEAM. 1993. "Whoomp! (There It Is)". Whoomp! (There It Is). De Tag Team (Steve Roll'n e DC the Brain Supreme), prod. Steve Roll'n e DC the Brain Supreme. Life Records, LR 78000-1.

TRINERE. 1986. "I'll Be All You Ever Need". De Tony Butler e Freestyle, prod. Pretty Tony. Jam Packed, JPI2001. 
O PATRÃO E A PADROEIRA:

MOMENTOS DE PERIGO NA PENHA, RIO DE JANEIRO

\section{Resumo}

O Baile da Chatuba é realizado desde meados dos anos 1990 na Quadra da Chatuba, Morro da Chatuba, parte do Complexo da Penha, na Zona Norte do Rio de Janeiro. A ocupação militar do Complexo da Penha em 2010 e a instalação de uma Unidade de Polícia Pacificadora (UPP) no Morro em 2012 restringiram o uso da Quadra, e o Baile foi suspenso. Em 2014 a Secretaria de Cultura do Estado patrocinou seu retorno, negociado entre os realizadores, integrantes da UPP, a Secretaria de Cultura, varejistas de substâncias ilícitas e moradores. Excluiu-se o subgênero de funk carioca cujas narrativas evocam a vida no crime: o proibidão, em função do qual o evento se tornara conhecido. Pesquisa histórica, análises fonográficas e trabalho de campo conduzido entre 2005 e 2015 reúnem-se nos âmbitos de uma antropologia urbana e de uma musicologia relacional (Born 2010) para inserir tal processo na história da criminalização das festas populares do bairro da Penha. Eximidos de uma visão linear e evolucionista da história (Benjamin 1985), a Festa da Penha e o Baile da Chatuba emergem como alegorias de uma história de longa duração das culturas da diáspora negra. Essa história articula criminalização e sobrevivência, e sugere que o proibidão seja parte de construções de identidade referenciadas nas experiências compartidas da violência armada e da violação de direitos.

Palavras-chave: Baile funk, Pacificação, Proibidão, Penha, Cultura de sobrevivência.

\section{THE BOSS AND OUR LADY: M OMENTS OF DANGER IN PENHA, RIO DE JANEIRO}

\section{Abstract}

The Baile da Chatuba (Chatuba dance) has taken place since the mid 1990s at the Quadra da Chatuba (Chatuba sports facility), on the Morro da Chatuba (Chatuba hill), which forms part of the Complexo da Penha (Penha complex of favelas), in the Zona Norte (northern region) of Rio de Janeiro city. Military occupation of the Complexo in 2010 and the installation of an Unidade de Polícia Pacificadora (pacifying police unit) on the hill in 2012 entailed restricted access to that facility, and the dances were forbidden. In 2014 the Secretaria de Cultura do Estado do Rio de Janeiro (Culture Bureau of the Rio de Janeiro State) sponsored their revival. There followed negotiations between the organizers, UPP officers, the Secretaria de Cultura, illicit-substance retailers, and the community. The subgenre of música funk (baile-funk music) that deals with life in crime, proibidão, for which Chatuba was renowned, ought to be excluded. Historical research, analyses of recordings, and fieldwork conducted from 2005 to 2015 come together within the frameworks of an urban anthropology and of a relational musicology (Born 2010) to inscribe such process in the history of the criminalization of popular partying in the Penha neighbourhood. Exempt from a linear and evolutionary view of history (Benjamin 1985), Festa da Penha (Penha Feast) and Baile da Chatuba appear as allegories of a long-haul history of the African-diaspora cultures. This history articulates criminalization and survival, and suggests that proibidão participates in the construction of identities whose references lie in shared experiences of armed violence and violation of rights.

Key words: Baile funk, Pacification, Proibidão, Penha, Survival culture. 
EL PATRÓN Y LA PATRONA:

MOMENTOS DE PELIGRO EN LA PENHA, RÍO DE J ANEIRO

\section{Resumen}

El Baile de la Chatuba se realiza desde mediados de los años 1990 en la Cancha de la Chatuba, Cerro de la Chatuba, parte del Complejo de la Penha, en la Zona Norte de Río de Janeiro. La ocupación militar del Complejo de la Penha en 2010 y la instalación de una Unidad de Policía Pacificadora (UPP) en el Cerro en 2012 restringieron el uso de la Cancha, y el Baile se suspendió. En 2014 la Secretaría de Cultura del Estado patrocinó su retorno, negociando entre los realizadores, integrantes de la UPP, la Secretaría de Cultura, vendedores al pormenor de substancias ilícitas y residentes locales. Se excluyó el subgénero del funk carioca cuyas narrativas evocan la vida en el crimen: el proibidão, en función del cual el evento se había vuelto conocido. Investigación histórica, análisis fonográficos y trabajo de campo realizado entre 2005 y 2015 se reúnen en los ámbitos de una antropología urbana y de una musicología relacional (Born 2010) para incorporar tal proceso en la historia de la criminalización de las fiestas populares del barrio de la Penha. Eximidos de una visión lineal y evolucionista de la historia (Benjamin 1985), la Fiesta de la Penha y el Baile de la Chatuba emergen como alegorías de una historia de larga duración de las culturas de la diáspora negra. Esa historia articula criminalización y supervivencia, y sugiere que el proibidáo es parte de construcciones de identidad referidas a experiencias compartidas de la violencia armada y de la violación de derechos.

Palabras-clave: Baile funk, Pacificación, Proibidão, Penha, Cultura de supervivencia. 